А.В.Мудрик, А.С.Макаренко, В.А.Сухомлинский и др.). Иными словами, речь идёт о формировании культуры вокально-хорового исполнительства учащихся начальной школы в культуротворческом контексте образования, определяющего интегративные личностно-значимые качества личности ученика на основе вокально-хоровых знаний, умений и навыков.

При такой расстановке акцентов ребёнку на уроках музыки в начальной школе предоставляется уникальная возможность приобрести навыки самосовершенствования, приблизиться к красоте. Известный педагог А.С.Макаренко считал, что «... красота самый лучший рычаг, заложенный в человеке, которым можно повернуть человека к культуре, красота - самый могучий магнит...» [5, с.66]. В свете представляемого решения нашей проблемы для нас значимо мнение С.А. Франкла, полагающего, что красота «...убедительное свидетельство некого таинственного родства между «внутренним» и «внешним» миром... » [6, с.606].

Постижение красоты в процессе организации вокально-хоровой работы на уроке музыки в школе - её сущность и имманентная потребность растущего человека. Логически выстроенная структура её содержания в начальной школе - постоянная инициация различных социокультурных понятий, согласовывающих и выстраивающихся в ценностные схемы, определяющих в дальнейшем жизненные позиции человека и выступающая сильным профилактическим средством, имеющим свойства стойкого иммунитета к различным асоциальным явлениям.

$$
* * *
$$

1. Бабанский Ю.К. Оптимизация учебно-воспитательного процесса: методологические основы [Текст] / Ю.К.Бабанский - М.: Просвещение, 1982. - 192с.

2. Баренбойм Л.А. Музыкальная педагогика и исполнительство [Текст] /М.: Изд-во «Музыка», 1974. $-335 \mathrm{c}$.

3. Корчак, Януш. Правила жизни / Януш Корчак, пер. с польского К.Сенкевич. - М.: Самокат, 2019. $288 \mathrm{c}$.

4. Лобанов И.В., Лобанова К.Ф. ПСТ: психология средствами театра. - СПб.: М.: Нестор-История, 2020. - 148c.

5. Макаренко А.С. Педагогические сочинения в 8-ми томах, Т.1. [Текст] / Сост. Л.Ю.Гордин, А.А.Фролов, М.: Педагогика, 1983. - 368c.

6. Франкл С.А. Сочинения [Текст]:Мн.: Харвест, М.: АСТ, 2000. - 800с.

Овсянникова А.Н., Мамаева А.B.

Возможности развития связной монологической речи с использованием метода мультипликации

Красноярский государственный педагогический университет им. В.П. Астафьева

doi: $10.18411 / s r-10-04-2021-53$

(Россия, Красноярск)

\title{
Аннотация
}

В статье рассматривается анализ проблемы связной монологической речи, проведен теоретический анализ процесса формирования связной речи, необходимость педагогического воздействия на детей с ОНР, представлен один из методов логопедической работы - мультипликация.

Ключевые слова: Речь, связная речь, общее недоразвитие речи, дети с ОНР, мультипликация.

Навык овладения богатейшим словарным запасом языка представляет важную и сложную задачу, в которую входит усвоение языковых законов и норм, закрепление языкового материала через умение логически связно, фонетически и лексически 
грамотно передать окружающим свою мысль, составить текст. Поэтому важным является научить ребенка полно и выразительно излагать свои мысли.

В современных условиях проблема формирования связной монологической речи становится очень актуальной, так как с одной стороны увеличивается число детей с нарушениями речевого генезиса, а с другой - процесс овладения связной речью усугубляется происходящим техническим усложнением человеческой коммуникации, замещением человеческого прямого общения, общением через электронные каналы связи и изменением, в связи с этим, самой модели речевого поведения. Выразительность и богатство формы связной монологической речи, ее сложная структура, которая служит для описания и выражения мыслей человека, в современном мире становится более емкой и целенаправленной, носит адресный характер, утрачивает свою гибкость, вариативность и модуляции. Но в тоже время, в связи с информатизацией общества, появляются новые возможности обучения с использованием различных технических средств, в том числе, специализированных компьютерных технологий, дидактических пособий, визуальных средств, обеспечивающих реализацию «обходных путей» коррекционного воздействия на речевые процессы.

При воспроизводстве монологической речи происходит более детальная внутренняя проработка и активизация речевых центров, чем при диалогической. Это обусловлено работой говорящего над содержанием, формой высказывания, характеризуется глубокой развернутой структурой и сложными лингвистическими конструкциями. Чтобы осуществить понятийную функцию, монолог необходимо структурировать полными, распространенными предложениями, используя для этого наиболее точный словарь. Особенности формирования связной речи и разработка обучающих методик по преодолению речевых нарушений были рассмотрены когортой ученых, а именно, В.К. Воробьевой, В.П. Глуховым, Т.А. Ткаченко, Н.С. Жуковой, Е.М. Мастюковой, Т.Б. Филичевой и другими.

У детей с общим недоразвитием речи процесс овладения связной речью отличается по временным и качественным параметрам от детей с нормотипичным уровнем речевого развития, это обуславливает необходимость развернутой помощи таким детям в преодолении речевых нарушений.

Многие авторы высказывают мнение о необходимости использования наглядных опор при составлении рассказов и пересказов: рекомендации Н.А. Чевелевой по развитию речи в процессе ручной деятельности, Т.А. Ткаченко предлагает использовать предметно-схематические модели предложений и рассказов. Также применение метода проектов в дошкольном детстве показывает высокую эффективность для развития связной монологической речи.

В настоящее время недостаточно систематизированных данных в области специальных разработок, комплексов занятий, материалов и рекомендаций, объединяющих данные подходы. Решением данной проблемы в части формирования связной монологической речи у детей 4-5 лет может стать создание видеоклипов или мультфильмов. Взаимодействуя в процессе съемки, дети с общим недоразвитием речи совершенствуют связную речь. Находясь в среде сверстников, каждый ребенок принимает участие в создании мультфильма. Ребята снимают кадры будущего мультфильма, через специальную программу получают готовый сюжет, а затем озвучивают его. Через визуальное восприятие мультфильма происходит стимуляция психической деятельности, а требующая коммуникации работа обуславливает активное участие ребенка и активизирует предпосылки формирования связной монологической речи. Дети учатся планировать и формулировать свою речь. Вовлеченность ребенка в творческий процесс благоприятным образом влияет на уверенность в себе и способствует раскрытию, как речевого потенциала, так и творческого. Мультфильм 
становится дверью в мир культуры и искусства, смыслов и ценностей, художественных образов и символов. Сопричастность ребенка к чему-то важному, а именно - созданию мультфильма, зарождает в нем чувство собственного достоинства и собственной значимости через осознание себя автором. Некоторые авторы полагают, что «потребность детей в признании и поддержке - это их стремление к общению, в результате которого они могут получить от окружающих оценку своей личности и реализовать стремление к общности с другими людьми». Таким образом, мультипликация понимается, как новый интересный и увлекательный инструмент удовлетворения ведущих коммуникативных мотивов ребенка. Озвучивание мультфильма, в котором дети принимают непосредственное участие, требует от воспитанников преодоления страхов и волнений. Задача педагога по преодолению нарушения, успокоить ребенка, убедить, что запись можно производить много раз, чтобы у него не возникало ощущение безысходности и укреплялась вера в собственные силы. С этой точки зрения, потенциал дидактической мультипликации огромен и включает в себя множество аспектов логопедической работы.

$$
* * *
$$

1. Воробьева В.К. Методика развития связной речи у детей с системным недоразвитием речи. М.: Астрель, 2006. $231 \mathrm{c.}$

2. Кудинова Ю.П., Мамаева А.В. Анализ существующих подходов к изучению деятельности общения // Вестник Красноярского государственного педагогического университета им. В.П. Астафьева. 2011. Т. 1. № 3. С. 139-144.

3. Колмыкова Н.В., Мамаева А.В. Метод проектов как средство развития связной монологической речи у старших дошкольников с общим недоразвитием речи // Вестник научных конференций. 2020. №12-1(64). С. 71-74.

4. Кольцова М.М. Ребёнок учится говорить. - М.: У-Фактория, 2006. 96 с.

5. Рубинштейн С.Л. Говори правильно. М.: Просвещение, 1990. 414c.

6. Селивёрстов В.И. Игры в логопедической работе. М.: Просвещение, 1978. 199c.

7. Фомичёва М.Ф. Воспитание правильного звукопроизношения у дошкольников. М.: Просвещение, $1971.212 \mathrm{c}$.

8. Шаховская С.Н. Логопедические занятия в детском саду для детей с нарушениями речи. М.: Педагогика,1992. 269 с.

\section{Огородникова Д.А. \\ Теоретические подходы к определению сферы бытовых услуг населения}

Оренбургский государственный университет (Россия, Оренбург)

doi: $10.18411 /$ sr-10-04-2021-54

\section{Аннотация}

В статье анализируются подходы к определению понятия «услуга», рассматриваются тенденции и причины роста третичного сектора экономики. Особое внимание уделяется исследованию сущности бытовых услуг и бытового обслуживания населения, рассматривается динамика объема оказанных бытовых услуг, выявляются тенденции и намечаются возможные направления развития сферы бытового обслуживания.

Ключевые слова: экономика, сектор услуг, сервис, третичный сектор, услуга, бытовая услуга.

Сегодня сфера бытового обслуживания представляет собой одну из важнейших отраслей для обеспечения жизнедеятельности населения. Рынок услуг в условиях современной экономики стал неотъемлемой частью потребительского рынка и отличается высокой насыщенностью. Несмотря на позитивные тенденции в сфере, 